\title{
Model kebijakan pengembangan sistem pertahanan sosial berbasiskan modal sosial masyarakat di daerah perbatasan
}

\section{Social defense policy model development system based on the society social modal in border area}

\author{
Asrinaldi \\ Jurusan Ilmu Politik, FISIP, Universitas Andalas. Telepon: (0751) 71266 \\ Jalan Limau Manis, Pauh, Padang 25163, Indonesia \\ E-mail: asrinaldi4@yahoo.com \\ Yoserizal \\ Jurusan Administrasi Negara, FISIP, Universitas Andalas. Telepon: (0751) 71266 \\ Jalan Limau Manis, Pauh, Padang 25163, Indonesia \\ E-mail: yose.unand@gmail.com
}

\begin{abstract}
A threat against the state is no longer in the forms of conventional war declarations or weaponary; but rather in the form of the loss of nationalism spirit due to the waning of national identity in a country. Along with the development of globalization, there is a shift regarding the threats against the state sovereignty. In Batam, Riau Province, as the border area, the threats include economic inequality between communities, the impact of trade liberalization, transnational crime, and the loss of collective identity due to the influence of globalization values using a qualitative approach, this article finds out that there are two forms of community respones related to social defense system; active and passive respones. However, in general, people in the border area in Batam respond more passively so that it affects the formation of the society defense system. In addition, this study also finds out that there are three stages in the formation of social defense system that can be used as a basis in policy formulation model for social defense system, including perception, togetherness, identification of collective action, as well as networking proliferation and regional integration.
\end{abstract}

Keywords: social defence system, threats to the state, social capital

\begin{abstract}
Abstrak
Ancaman negara saat ini tidak lagi intimidasi yang berbentuk perang konvensional dengan menggunakan persenjataan dengan teknologi tinggi. Justru ancaman yang ditakuti saat ini adalah hilangnya semangat nasionalisme karena memudarnya nilai-nilai identitas bersama pada suatu negara. Seiring dengan perkembangan globalisasi dalam sistem internasional, maka terjadi perubahan ancaman terkait dengan kedaulatan suatu negara. Ancaman yang menyertai masyarakat di daerah perbatasan di Batam Provinsi Kepulauan Riau meliputi ketidakadilan ekonomi antara masyarakat, liberalisasi perdagangan yang berdampak pada kejahatan transnasional dan hilangnya identitas bersama akibat pengaruh nilai-nilai asing. Dengan menggunakan pendekatan kualitatif, artikel ini menemukan bahwa ada dua bentuk respon masyarakat di daerah perbatasan dalam membentuk sistem pertahanan sosial, yaitu secara aktif dan secara pasif. Namun, pada umumnya masyarakat di daerah perbatasan di Batam lebih cenderung meresponnya secara pasif sehingga berdampak pada lambatnya pembentukan sistem pertahanan sosial dalam masyarakat. Selain itu, artikel ini juga menemukan bahwa ada tiga tahapan dalam pembentukan sistem pertahanan sosial yang dapat dijadikan dasar dalam menyusun model kebijakan pengembangan sistem pertahanan sosial masyarakat di daerah perbatasan, yaitu penyamaan persepsi dan kebersamaan, identifikasi tindakan bersama dan proliferasi jaringan dan integrasi wilayah.
\end{abstract}

Kata kunci: sistem pertahanan sosial, ancaman negara, modal sosial 


\section{Pendahuluan}

Artikel ini terkait dengan usaha mengembangkan model kebijakan sistem pertahanan sosial yang relevan untuk masyarakat perbatasan sesuai dengan potensi ancaman di daerah Batam. Pengembangan kebijakan untuk antisipasi tersebut dilakukan dengan memanfaatkan modal sosial dalam upaya membangun sistem pertahanan sosial (social defence) yang bersifat non kekerasan dan non militer. Keberadaan modal sosial dalam masyarakat untuk mendorong keterlibatan mereka dalam aktivitas bernegara, berbangsa dan bermasyarakat sudah menjadi perhatian banyak pihak. Misalnya, Chenhall, Hall \& Smith (2010) melihat peran modal sosial dalam sistem kendali menajemen dalam pelaksanaan pembangunan. Begitu juga dengan Lowndess \& Pratchett (2008) yang menegaskan pentingnya modal sosial dalam kebijakan publik. Justru, aspek pengembangan sistem pertahanan sosial dengan memanfaatkan modal sosial ini jarang mendapat perhatian sarjana padahal ia sangat relevan dengan kondisi Indonesia yang majemuk dengan dengan sistem sosiobudaya. Hal penting dalam mengembangkan sistem pertahanan sosial dengan mengolah modal sosial yang ada dalam masyarakat.

Pengembangan sistem pertahanan sosial ini penting karena potensi ancaman yang datang kepada masyarakat di daerah Batam adalah kesenjangan ekonomi yang terkait dengan keadilan sosial antara masyarakat tempatan dengan pendatang, liberalisasi perdagangan mendorong terjadinya kejahatan transnasional, dan memudarnya identitas bersama dalam masyarakat di daerah perbatasan. Ancaman ini jelas membawa pengaruh pada interaksi sosial masyarakat Batam yang heterogen. Oleh karena itu, artikel ini memfokuskan pembahasan pada bentuk respon masyarakat di daerah perbatasan terkait dengan ancaman yang datang kepada mereka. Selain itu, pembahasan dalam artikel ini juga di arahkan pada perumusan model kebijakan untuk pengembangan sistem pertahanan sosial berbasiskan modal sosial masyarakat di daerah perbatasan, khususnya di Batam.

\section{Modal sosial untuk pengembangan sistem pertahanan sosial}

Usaha untuk menguatkan sistem pertahanan nasional memang menjadi perhatian banyak pemimpin negara di dunia. Namun pilihan untuk menguatkan sistem pertahanan dan keamanan negara ini lebih difokuskan kepada peningkatan sistem persenjataan dan teknologi militer. Sayangnya, tidak banyak pemimpin negara memberi perhatian kepada membangun sistem pertahanan nasional yang bersifat non militer seperti membangun sistem pertahanan berbasiskan masyarakat. Dalam konteks ini, pertahanan sosial yang dimaksudkan jelas bukan merujuk kepada kekuatan persenjataan atau kemampanan teknologi militer, namun berkaitan dengan tindakan rakyat sebuah negara untuk menjaga sistem pemerintahan, ekonomi, sosial, budaya, politik, pendidikan, dan sebagainya dari invasi negara lain. Tindakan penduduk suatu negara merespon ancaman, tantangan, gangguan dan hambatan baik yang berasal dari dalam dan terutama yang datang dari luar negara dapat dicegah jika modal sosial masyarakat kuat.

Putnam (1993) menjelaskan modal sosial pada dasarnya menggambarkan bagaimana individu menggunakan hubungannya dengan individu lain dalam masyarakat untuk melakukan kebaikan bersama berdasarkan tanggungjawab, hubungan saling percaya dan peran masing-masing. Berdasarkan hubungan saling percaya ini mereka dapat membentuk jaringan sosial untuk melakukan tindakan bersama (collective action). Pertahanan sosial atau dikenal juga dengan pertahanan berbasiskan masyarakat sipil (civilian-based defence) merupakan strategi alternatif pertahanan yang menggunakan tindakan non kekerasan (non violence) untuk mempertahankan dan menghadapi serangan militer yang dilakukan pihak musuh. Pertahanan sosial ini mengambil beberapa bentuk seperti mengadakan rapat umum, non kooperatif dengan musuh, melakukan mogok, tindakan boikot dan tindakan protes melalui organisasi sosial yang dimasuki individu (Martin 1987, Wollongong 1994). 
Menurut Martin (1987, 1993) pertahanan sosial adalah mekanisme pertahanan alternatif tanpa menggunakan kekuatan militer. Menurut Martin (1993:4)

Social defence is nonviolent community resistance to aggression as an alternative to military defence. It is based on widespread protest, persuasion, noncooperation and intervention in order to oppose military aggression or political repression. It uses methods such as boycotts, acts of disobedience, strikes, demonstrations and setting up alternative institutions.

Dalam realitanya, sistem pertahanan berbasiskan kekuatan sosial masyarakat ini cukup efektif menghentikan gerak maju pasukan musuh dalam perang yang sedang dihadapi. Ini dapat dilihat dari tindakan Gandhi yang berjuang tanpa kekerasan menghadapi penjajahan menjadi alternatif membentuk sistem pertahanan sosial bagi banyak negara di dunia (Gregg 1966). Begitu juga masyarakat Eropa yang menolak invasi Nazi ketika menduduki Eropa dalam perang dunia ke-2 serta tindakan masyarakat Chekoslovakia menghalangi gerak maju pasukan Uni Soviet yang menginvasi wilayah mereka tahun 1968. Jadi, pengalaman banyak negara di dunia yang berhasil menggunakan mekanisme pertahanan sosial dalam menjaga wilayahnya menjadi inspirasi bagi negara lain untuk mengembangkannya.

Rakyat Indonesia juga memiliki pengalaman berkaitan dengan sistem pertahanan sosial ini. Misalnya, ini dapat dilihat ketika mereka menghadapi kolonial Belanda dan Jepang sebelum kemerdekaan. Begitu pentingnya sistem pertahanan sosial ini mendorong Kementerian Pertahanan (2008:116-118) membangun sistem pertahanan yang bersifat pertahanan semesta yang melibatkan dua komponen utama, yaitu Tentara Nasional Indonesia (TNI) dan warga negara. Apalagi ini sangat sejalan dengan sejarah terbentuknya tentara di republik ini. Menurut Crouch (1978) sejarah pembentukan TNI juga tidak terlepas dari keterlibatan rakyat Indonesia mempertahankan kemerdekaan Indonesia dari penjajahan Belanda dan Jepang. Pengembangan sistem pertahanan nasional berdasarkan kekuatan rakyat bukanlah sesutau yang bersifat a-historis. Sebaliknya, sistem pertahanan nasional yang sudah ada ini telah mengakar ke dalam kehidupan rakyat Indonesia (Nasution 1980).

Sistem pertahanan sosial sebenarnya dapat dibentuk dan dikembangkan dari sistem sosio-budaya masyarakat lokal. Sistem sosio-budaya lokal ini dapat dilihat dari kebiasaan masyarakat di sebuah negara yang saling berinteraksi dan saling terikat satu dengan yang lainnya yang dikenal dengan modal sosial (Putnam 1993, Fukuyama 1995, Lowndess \& Pratchett 2008). Lebih jauh Fukuyama (1995) menjelaskan bahwa modal sosial adalah nilai-nilai dan norma informal dalam masyarakat yang dikongsi bersama sebagai dasar kerjasama dan membangun kepercayaan satu dengan yang lain. Pendapat yang sama juga pernah dikemukakan Putnam (1993:167) yang menyatakan modal sosial adalah "norms of reciprocity and networks of civic engagement." Dalam modal sosial tercermin hubungan timbal balik dalam masyarakat yang terjalin melalui interaksi dan keterlibatan mereka.

Bahkan modal sosial dapat dikaitkan dengan kebijakan publik karena menjadi sumber dalam proses pembuatan kebijakan tersebut menyatu dengan aspek lain seperti keuangan, sumber daya manusia dan infrastruktur lainnya. Menurut Lowndess \& Pratchett (2008:677) "a policy resource — an input to policy making and implementation alongside financial capital (revenue, investment), human capital (skills, individual capacities, knowledge) and physical capital (buildings, equipment)". Singkatnya, modal sosial dapat menjelaskan hubungan yang terbentuk antara masyarakat sipil, negara dan kebijakan pemerintah, khususnya dalam penyelenggaraan fungsi pemerintahan.

Keberadaan modal sosial ini menjadi pertimbangan bagi banyak pihak, terutama dihubungan dengan membangun sistem pertahanan negara. Apalagi di Indonesia tidak dibedakan secara tegas antara penduduk sipil dengan kombatan dan jaminan perlindungan terhadap penduduk sipil dalam masa perang menurut hukum internasional (Istanto 1992). Apalagi di Indonesia sistem pertahanan yang dibangun ini juga terkait dengan pertahanan rakyat semesta yang dinyatakan dalam UUD 
1945 yakni sistem pertahanan yang mengikutsertakan seluruh rakyat dalam komponen Rakyat Terlatih (Ratih), Angkatan Bersenjata Republik Indonesia (ABRI), Perlindungan Masyarakat (Linmas), dan pemanfaatan sumber daya.

Connie Rahakundini dalam bukunya yang berjudul Pertahanan negara dan postur TNI ideal (2007) juga melihat adanya keinginan pemerintah membangunan kemampuan sistem pertahanan rakyat semesta dengan melibatkan rakyat, TNI dan Polri sebagai kekuatan utama. Keterlibatan masyarakat dalam membangun sistem pertahanan sosial ini menjadi isu penting dibanyak negara karena bentuk ancaman dalam konteks globalisasi saat ini bukanlah ancaman militer seperti yang dikhawatirkan oleh kelompok realis. Akan tetapi ancaman yang bersifat non militer. Sayidiman Suryohadiprojo (2005) menjelaskan tantangan yang dihadapi negara Indonesia dalam membangun sistem pertahanan negara adalah terkait dengan ancaman terhadap tapal batas negara. Mudahnya mobilitas masyarakat internasional melewati batas-batas geografis suatu negara berdampak pada masuknya nilai-nilai ideologi yang dapat mempengaruhi sistem nilai masyarakat di suatu negara.

\section{Metode Penelitian}

Penelitian yang dilakukan di Batam ini mengunakan pendekatan kualitatif dengan teknik grounded theory. Teknik ini sesuai untuk membangun konsep baru yang terkait dengan pengembangan sistem pertahanan sosial di daerah perbatasan. Data dikumpulkan melalui wawancara mendalam dan pengamatan terkait dengan aktivitas masyarakat di Kota Batam dalam hubungannya dengan modal sosial yang mereka miliki. Analisis dalam penelitian ini menggunakan interpretasi etik dan emik seperti yang lazim dikenal dalam penelitian pendekatan kualitatif.

\section{Respon dan tindakan masyarakat perbatasan dalam membangun sistem pertahanan sosial}

Persoalan yang paling mendasar yang dihadapi masyarakat di daerah perbatasan adalah cara pandang mereka terhadap negara tetangga dan respon mereka terhadap sistem nilai yang berlaku. Misalnya, masyarakat di daerah perbatasan di Batam yang akrab dengan sistem nilai liberal dan kapitalis yang berasal dari Singapura dan Malaysia. Kedua negara ini sangat intensif membangun hubungan ekonomi dengan Indonesia. Keadaan ini menjadi bagian lingkungan penting yang ada dalam kehidupan masyarakat Batam. Hal ini jelas berbeda dengan masyarakat di daerah perbatasan seperti di Nusa Tenggara Timur yang berbatasan dengan Negara Timor Leste. Sejarah hubungan diplomatik antara Indonesia dan Timor Leste yang dimulai dengan konflik dan perang sehingga mempengaruhi cara pandang masyarakat di daerah perbatasan. Menurut Ganewati (2009:7) masalah perbatasan di daerah Nusa Tenggara Timur ini cukup kompleks karena berhadapan dengan masalah lintas batas, termasuk di dalamnya masalah pembangunan sosio-ekonomi, kesehatan, lingkungan dan pertahanan dan keamanan.

Dominannya faktor lingkungan masyarakat mempengaruhi pembentukan preferensi nilai-nilai yang bermuara pada pembentukan respon mereka. Jadi respon masyarakat yang hidup di daerah perbatasan dengan lingkungan konflik militer yang dominan, jelas berbeda dengan respon masyarakat yang hidup di daerah perbatasan yang bernuansa non konflik. Di sinilah letak pentingnya pengaruh preferensi nilai individu dalam pembentukan persepsi terhadap lingkungan yang akan diresponnya (Greenstein 1975).

Masyarakat di daerah perbatasan di Batam menghadapi persoalan nilai yang dipengaruhi aktivitas liberalisasi ekonomi dan perdagangan internasional (Asrinaldi \& Yoserizal 2013). Walaupun mereka tidak menjadi pelaku langsung dalam aktivitas tersebut, namun aktivitas liberalisasi ekonomi dan perdagangan ini berada dalam kehidupan mereka. Hal ini yang menyebabkan terjadinya konflik nilai dalam diri mereka. Konflik nilai ini jika dibiarkan terus menerus dapat merusak keyakinan mereka terhadap sistem nilai yang menjadi dasar keyakinan mereka dalam meyakinkan ideologi berbangsa dan bernegara. Menurut Claessen \& Oosten (1996), sistem ideologi berbangsa dan bernegara ini dibangun dari proses kesejarahan yang panjang yang secara intensif 
melibatkan interaksi aparatur negara dan masyarakat, keterlibatan lembaga-negara, khususnya dalam negara yang baru berdiri. Ideologi bersama yang terbangun ini dapat menjalin kebersamaan dalam mewujudkan tujuan berbangsa dan bernegara yang baru terbentuk.

Namun yang perlu diwaspadai adalah ketika pemerintah dan sekolah mulai menurun intensitasnya menyosialisasikan hakikat rasa kebangsaan ini kepada masyarakat, terutama yang hidup di daerah perbatasan. Hal ini juga akan berdampak pada semakin melemahnya ikatan rasa kebangsaan yang "diciptakan" oleh negara. Masyarakat di daerah perbatasan seperti di Batam, disadari atau tidak, telah menjadi bagian dari masyarakat internasional. Apalagi jika dilihat dari interaksi keseharian mereka yang lebih banyak dipengaruhi oleh aspek ekonomi dan perdagangan dari Singapura dan Malaysia yang memang lebih baik dari Indonesia. Keadaan ini justru menjadi pemicu munculnya sejumlah pemikiran kritis dalam masyarakat di Batam yang mulai mempertanyakan hak mereka sebagai warga negara. Selama ini, pemerintah memang kurang memperhatikan kehidupan masyarakat di daerah perbatasan ini sehingga mempengaruhi cara pandang mereka terhadap Jakarta.

Secara tidak langsung masalah ini jelas menjadi ancaman bagi sistem pertahanan negara. Secara teori, masyarakat adalah komponen cadangan dalam membangun sistem pertahanan secara konvensional. Dalam keadaan perang, keterlibatan masyarakat sebagai komponen cadangan menjadi penting untuk mepertahankan kedaulatan negara. Apalagi masyarakat yang berada di daerah perbatasan. Namun, jika pemerintah gagal membangun semangat kebangsaan, terutama bagi mereka yang tinggal di daerah perbatasan, fenomena ini akan membawa dampak serius bagi kedaulatan negara. Sebab, ancaman terhadap invasi militer di negara yang saling berbatasan adalah sesuatu yang nyata dalam sistem pertahanan konvensional.

Namun, seiring dengan perkembangan zaman yang menyebabkan negara-negara semakin terintegerasi ke dalam sistem global, menyebabkan militer tidak lagi menjadi ancaman utama terhadap kedaulatan negara. Justru, ancaman non militer yang dominan mempengaruhi sistem pertahanan suatu negara. Karena ancaman non militer ini dapat membawa pengaruh yang hebat pada kemunculan konflik, kekerasan dan bahkan perang saudara. Contoh nyata yang dapat dilihat saat ini adalah fenomena demokratisasi di dunia Arab. Perubahan nilai politik masyarakat yang selama ini mereka yakini dengan sistem otoritarian dan sistem monarki akhirnya bergeser menjadi sistem demokrasi. Bahkan pergeseran ini berdampak buruk bagi keamanan negara. Transisi ke demokrasi di beberapa negara-negara di Timur Tengah seperti Mesir, Libya, dan Suriah berakhir dengan konflik dan kekerasan. Bahkan yang patut dikhawatirkan dari konflik ini adalah menjurus pada perang saudara. Singkatnya, perubahan ini jelas merupakan implikasi bergesernya preferensi nilai politik individu warga negara yang dipengaruhi oleh sistem politik internasional. Ini dapat terjadi karena sistem politik internasional menghasilkan nilai-nilai universal yang diterima oleh komunitas internasional (Kaplan 2005). Nilai-nilai inilah yang diserap dan dijadikan pedoman. Misalnya, terkait dengan perkembangan demokrasi yang sebagian besarnya hampir dapat diterima oleh semua negara di dunia.

Adanya pengaruh nilai-nilai internasional dalam kehidupan masyarakat juga dapat dilihat di Indonesia. Pergeseran preferensi nilai individu di daerah perbatasan, khususnya di daerah Batam juga tengah berlangsung. Pada umumnya orientasi masyarakat yang hidup di daerah perbatasan cenderung dipengaruhi oleh lingkungan di sekitarnya, termasuk dalam hal ini negara-negara yang berbatasan dengan tempat mereka berdomisili. Apalagi jika negara-negara yang menjadi bagian lingkungan kehidupan mereka ini jauh lebih maju dengan negara dimana mereka berdomisili. Inilah yang tengah terjadi dalam kehidupan masyarakat Batam.

Pemerintah pun menyadari realita ini sehingga mengubah pendekatan dalam mengelola daerah perbatasan dari pendekatan militer ke pendekatan kesejahteraan (Ganewati 2009). Dalam rentang empat tahun terakhir pemerintah pun membentuk Badan Nasional Pengelola Perbatasan berdasarkan Peraturan Presiden No. 12 tahun 2010 yang ditindak lanjuti dengan pembentukan Badan Pengelola Perbatasan Daerah di setiap provinsi yang berbatasan dengan negara tetangga. 
Salah satu tugas yang diamanatkan dari badan pengelola ini adalah perencanaan dan pelaksanaan pembangunan di daerah perbatasan. Inilah yang ditegaskan oleh Kepala Badan Pengelolaan Perbatasan daerah provinsi Kepulauan Riau bahwa perlunya perubahan dalam mengelola daerah perbatasan dari pendekatan keamanan ke pendekatan kesejahteraan (Sofiyan 2013).

Perubahan paradigma pengelolaan perbatasan dari security approach ke prosperity approach ini sangat mendasar. Jika pada pendekatan pertama cenderung mengandalkan pada keterlibatan militer dalam mengawal daerah perbatasan, maka pada pendekatan terakhir justru mengandalkan partisipasi masyarakat. Pemerintah Daerah Provinsi Kepulauan Riau menyadari betul bahwa permasalahan dalam pengelolaan daerah perbatasan tidak hanya menyangkut tapal batas dan kedaulatan negara saja (Sofiyan 2013).

Sebenarnya banyak persoalan yang dihadapi masyarakat di daerah perbatasan ini, terutama menyangkut pendidikan, infrastruktur, masalah kemiskinan, kesehatan, telekomunikasi dan perhubungan. Karenanya mengatasi masalah ini tidak hanya ada pada pemerintah, tapi juga melibatkan masyarakat. Dari aspek inilah pendekatan pengelolaan perbatasan tersebut harus diubah sesuai dengan dinamika yang ada dalam masyarakat.

Dengan mengandalkan pendekatan kesejahteraan ini sebenarnya pemerintah tengah melakukan perubahan dalam mengelola sistem pertahanan negara, yaitu dengan membangun sistem pertahanan sosial. Sistem pertahanan sosial, seperti yang dijelaskan Martin (1993) adalah salah satu kaedah pertahanan yang meninggalkan cara-cara militer dalam mempertahankan suatu negara dari ancaman dari negara lain. Strateginya adalah dengan melibatkan masyarakat untuk mempertahankan kedaulatan negara. Kesadaran masyarakat tentang pentingnya kedaulatan negara ini dapat dibangun, jika kesejahteraan masyarakat meningkat. Dengan keadaan ini, maka akan muncul rasa memiliki masyarakat terhadap lingkungan dimana mereka berdomisili. Secara tidak langsung, jika ada ancaman yang datang mengganggu lingkungan mereka, maka secara sadar masyarakat akan merespon untuk mempertahankan lingkungan mereka dari ancaman yang ada.

Sistem pertahanan sosial dapat menjadi alternatif dalam memperkuat sistem pertahanan konvensional. Dengan kata lain, sistem pertahanan konvensional yang mengandalkan kekuatan militer tidak cukup efektif mempertahankan negara di tengah terjadinya perubahan dunia. Sistem politik internasional yang berubah cepat tidak lagi memandang konflik suatu negara adalah dengan negara lain. Sebaliknya, konflik dalam benegara justru muncul karena tuntutan masyarakat karena dipengaruhi oleh nilai-nilai yang menyertai proses globalisasi seperti keadilan, kesejahteraan, hak asasi dan demokrasi. Oleh karena itu, mempertahankan negara dari ancaman terhadap kedaulatan yang datang dari luar bukanlah trend yang tengah berkembang. Kecenderungan sekarang adalah pemerintah di banyak negara berusaha mengaktifkan keterlibatan masyarakat dalam membendung sistem nilai global yang datang dari luar yang dapat memicu ketegangan negara dengan warganya.

Fakta ini juga tengah berlangsung di daerah perbatasan seperti Batam. Kota Batam adalah salah satu daerah perbatasan yang tingkat perekonomiannya cukup maju dibandingkan dengan daerah perbatasan lain. Perkembangan ekonomi yang begitu pesat yang dimulai dengan sejak dijadikannya Batam ini sebagai daerah otorita pada masa Orde Baru. Gambaran perkembangan Pulau Batam yang cepat ini juga dapat dilihat dari perkembangan jumlah penduduknya yang sangat pesat, yaitu dari 6000 orang tahun 1970 menjadi 1,2 juta masyarakat tahun 2012. Salah satunya adalah dampak dari kemajuan ekonomi di daerah ini sehingga mendorong terjadinya migrasi masyarakat ke Pulau Batam. Akibatnya Batam menjadi tujuan kaum migran mencari kerja dari berbagai daerah. Salah satu dampaknya adalah komposisi masyarakat Batam yang cenderung heterogen sehingga mempengaruhi interaksi yang terjadi di antara mereka. Menariknya justru komposisi penduduknya yang heterogen dari berbagai etnis seperti Melayu, Jawa, Batak, Minang, Tionghoa, Bugis, Banjar dan sebagainya memiliki jumlah yang hampir sama banyak di daerah ini. Keadaan ini tentu memberi nilai plus-minus terkait dengan upaya membangun sistem pertahanan sosial dengan mengandalkan masyarakat yang heterogen ini. 
Salah satu dampak negatif dari heterogenitas masyarakat Batam ini adalah potensi muncul ketegangan dan bahkan konflik antar etnik. Karenanya pemerintah daerah berupaya membuat kebijakan yang dapat mengantisipasi munculnya konflik etnik. Salah satu kebijakan yang diambil oleh pemerintah daerah adalah menghidupkan paguyuban etnik tertentu. Paguyuban ini menjadi institusi yang cukup efektif bagi pemerintah daerah dalam menyelesaikan ketegangan etnik yang terjadi di Batam. Selain itu, dalam konteks formal, Pemerintah Kota Batam juga membuat institusi formal, yaitu Forum Pembauran Kebangsaan (FPK) yang bertujuan untuk mengintegrasikan etnik agar dapat menyelesaikan masalahnya secara damai (Bantun 2013).

Adanya keinginan warga berhimpun dalam paguyuban etnik dan FPK yang dibentuk oleh pemerintah kota menjadi modal sosial bagi pengembangan sistem pertahanan yang bersifat non militer. Modal sosial yang berkembang dalam masyarakat ini menjadi dasar terjalinnya interaksi di antara individu yang terkait dengan perwujudan kepentingan bersama. Tidak hanya itu, interaksi yang terjadi juga melibatkan individu dengan organisasi sosial yang ada hasil bentukan masyarakat sendiri maupun pemerintah daerah.

Realita ini juga semakin mengaskan bahwa masyarakat memiliki respon yang positif, terutama untuk membangun sistem pertahanan sosial. Persoalannya adalah bagaimana pemerintah menstimulasi agar respon masyarakat muncul sehingga sistem pertahanan sosial di daerah perbatasan ini dapat dibentuk. Jika dilihat lebih jauh, sistem pertahanan sosial yang terbentuk masih dalam taraf sederhana. Sistem pertahanan sosial dalam masyarakat di Batam bukanlah dalam pengertian sistem pertahanan untuk mengantisipasi serangan militer seperti yang dikonsepsikan oleh Martin (1993) dan Wolonggong (1994). Dalam konteks ini, sistem pertahanan sosial yang terbangun dalam masyarakat masih dalam rangka mengantisipasi ketegangan yang dapat bermuara pada konflik sosial di antara individu dan kelompok. Peran pemuka adat dan agama menjadi strategis dalam masyarakat Batam yang heterogen. Seperti yang dijelaskan Sugiyanto (2013) Kasi Pembangunan dan Pemberdayaan Masyarakat Kecamatan Batu Ampar:

Kalaupun ada, itu gejolak yang tidak berarti karena selalu disikapi secara bijak dan secepatnya pak. Kalau umpamanya ada konflik, mungkin bapak pernah dengar bahwa dulu ada konflik antara Flores dan Batak, alhamdulillah segera mungkin dapat diredam melalui tokoh-tokoh agama dan tokoh-tokoh suku.

Artinya, nilai adat dan agama menjadi dasar pembentukan mekanisme sistem pertahanan sosial dalam masyarakat agar dapat hidup harmoni. Begitu juga dengan tokoh adat dan tokoh agama di Batam masih memiliki otoritas dalam komunitas masing-masing untuk mempengaruhi sikap dan perilaku masyarakatnya. Namun, faktor adat dan agama belum sepenuhnya dapat dikembangkan menjadi bagian dari sistem pertahanan.

Pertanyaannya sekarang, bagaimana respon dan tindakan masyarakat dalam membentuk sistem pertahanan sosial? Dalam konsepsinya, sistem pertahanan sosial adalah satu kesatuan tindakan yang terbentuk dalam masyarakat berdasarkan modal sosial untuk mempertahankan kedaulatan wilayah masyarakat atau negara. Tindakan adalah bagian respon individu yang muncul karena adanya pengetahuan dan pemahaman terhadap lingkungannya yang menjadi stimulus (Zuckerman 2005). Pengetahuan dan pemahaman inilah yang menjadi dasar pembentukan sikap dan tindakan apa yang akan dilakukan oleh individu tersebut. Jika dihubungkan dengan nilai adat dan agama, maka kedua aspek nilai ini menjadi pengetahuan dan pemahaman dasar bagi individu untuk merespon stimulus yang datang pada mereka. Dengan demikian, pembentukan tindakan terhadap ancaman dan gangguan yang datang dari luar diri individu sebenarnya menjadi stimulus untuk direspon. Misalnya, yang terkait dengan ketegangan dan konflik yang terjadi di antara etnik yang hidup di Batam dipahami sebagai ancaman dan gangguan bagi individu sehingga perlu di respon dengan baik. Dengan adanya pengetahuan dan pemahaman tentang adat dan agama, maka ancaman dan gangguan tersebut dapat diminimumkan melalui saling pengertian dan kerjasama di antara etnik-etnik tersebut. Saling pengertian dan kerjasama inilah yang menjadi modal sosial dan 
sekaligus menjadi bagian dari respon individu dalam upaya membangun sistem pertahanan sosial tersebut. Proses pembentukan respon tersebut dapat dilihat dari penjelasan gambar 1 berikut ini.

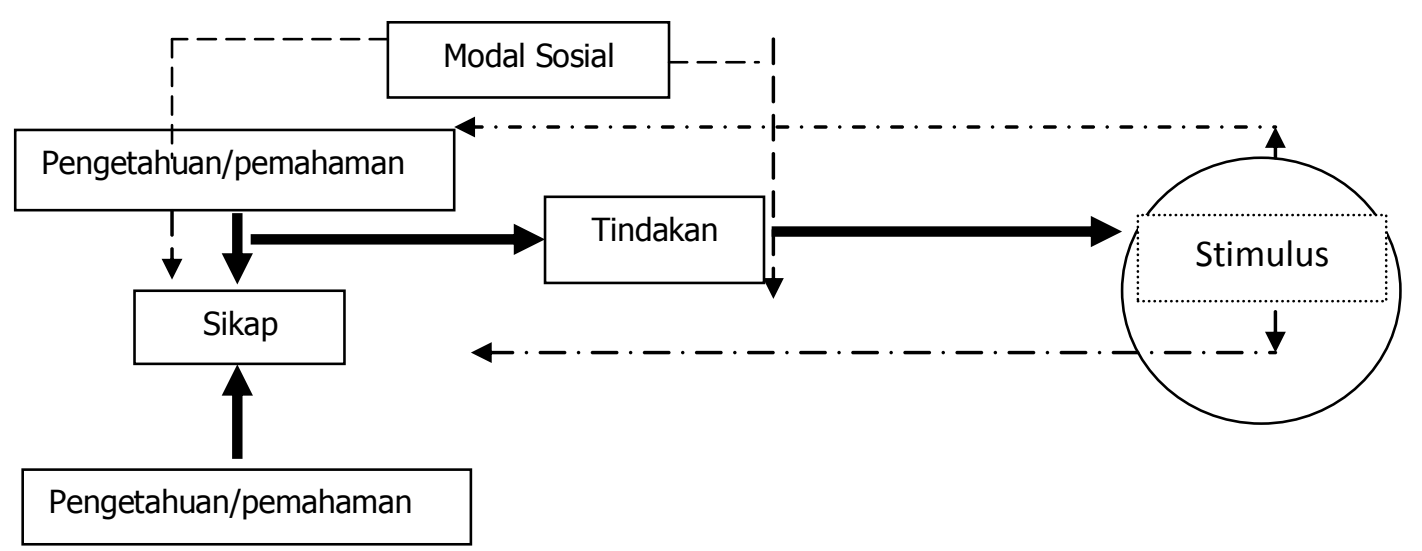

Gambar 1.

Proses pembentukan respon dan tindakan dalam sistem pertahanan sosial

Dilihat dari respon yang diberikan masyarakat terkait dengan upaya membangun sistem pertahanan sosial tersebut, maka dapat dikelompok ke dalam dua bentuk, yaitu respon pasif dan respon aktif. Pengertian respon pasif yang dimaksudkan di sini adalah upaya individu merespon stimulus yang datang kepadanya, namun dalam bentuk tindakan yang minimum seperti berdiam diri, menghindari dan membiarkan stimulus tersebut. Hal ini terjadi karena pengetahuan dan pemahaman individu sangat sedikit tentang stimulus yang datang kepadanya. Akibatnya respon yang diberikan menjadi minimal. Contohnya, kuatnya pengaruh nilai liberalisme dan kapitalisme membawa dampak kepada masyarakat di Batam. Namun, karena sedikitnya pengetahuan masyarakat tentang hal tersebut berdampak pada respon yang mereka berikan. Akibatnya masyarakat cenderung membiarkan fenomena tersebut mepengaruhi kehidupan mereka, terutama dalam pengertian yang negatif.

Sementara respon aktif adalah upaya individu merespon stimulus yang datang dengan cara-cara progresif seperti menentang, menghadapi dan mengarahkan respon tersebut sesuai dengan keinginan mereka. Cara respon yang aktif ini muncul karena individu-individu ini memiliki pengetahuan dan pemahaman yang baik terhadap stimulus yang datang kepadanya. Dengan demikian, responnya menjadi maksimal. Namun, melihat kecenderungan yang terjadi di Batam, pada umumnya masyarakat di daerah ini memiliki respon pasif. Masyarakat di daerah ini cenderung membiarkan stimulus yang datang tanpa memberikan respon yang berarti.

Jika demikian, apa implikasinya pada upaya membangun sistem pertahanan sosial? Lazim diketahui, salah satu aspek penting dalam membangun sistem pertahanan sosial adalah kesadaran masyarakat tentang adanya ancaman yang menjadi stimulus dan harus segera direspon. Karena secara teori, pertahanan sosial hanya dapat dibangun jika modal sosial dalam masyarakat tersebut berkembang baik. Sebab, tanpa modal sosial, maka tidak akan terbangun ikatan kebersamaan dan saling percaya, terutama dalam mempertahankan wilayah dari ancaman nilai-nilai luar yang bertentangan dengan kebiasaan masyarakat setempat. Sistem pertahanan sosial ini terbentuk karena ada peran dan tanggung jawab sosial individu di lingkungannya. Saling percaya di antara individu ini menjadi ikatan yang kuat sehingga terbentuk jaringan sosial yang mendorong tindakan bersama. Inilah yang menjadi dasar pembentukan pertahanan sosial di daerah perbatasan.

Sayangnya sistem pertahanan sosial yang terbentuk pada masyarakat di daerah perbatasan ini masih belum jelas bentuknya. Ini karena ikatan sosial yang terbentuk di daerah ini hanya berdasarkan ikatan etnis yang cenderung tertutup. Artinya, jaringan kebersamaan masih sebatas ikatan primordial kesukuan. Padahal masalah yang dihadapi adalah masalah sistem nilai global yang menjadi ancaman nyata untuk masyarakat di Batam. Bahkan dalam kasus tertentu, terjadi pula ketegangan antar etnik di Batam karena masalah tanah. Ketegangan ini adalah implikasi dari 
penyerobotan lahan tidur oleh etnik tertentu yang sebenarnya milik perusahaan, namun pengawasan dilakukan oleh etnik lain (Sofiyan 2013). Keadaan ini jelas menjadi kendala dalam membangun sistem pertahanan sosial tersebut. Misalnya, kasus konflik kepemilikan tanah antara masyarakat setempat dengan kelompok masyarakat "suruhan" pengusaha di Tanjung Uma tanggal 23 Oktober 2013 (Tempo 2013). Kejadian seperti ini bukanlah yang pertama terjadi di Kota Batam. Ke depan persaingan untuk menguasai aset seperti tanah ini akan terus meningkat seiring dengan semakin berkurangnya kewenangan Otorita Batam. Pelaksanaan otonomi daerah mendorong pemerintah lokal untuk mengembangkan potensi yang dimilikinya, termasuk penguasaan terhadap aset yang dikelola oleh Pihak Otorita Batam selama ini.

Walaupun begitu, upaya mengintegrasikan etnik tersebut dalam suatu forum bersama untuk memperkuat rasa kebersamaan dan saling percaya di antara etnik-etnik yang ada juga terus dilakukan pemerintah daerah. Menurut Kepala Bidang Penanganan Masalah Aktual Badan Kesatuan Bangsa dan Politik Kota Batam agar konflik di antara etnik dapat diminimumkan, maka dibentuk pula Forum Kewaspadaan Dini yang keanggotaannya melibatkan semua elemen etnik yang ada di Batam (Sofiyan 2013).

Jadi dapat disimpulkan respon dan tindakan masyarakat dalam pembentukan Sistem Pertahanan Sosial masih mengalami hambatan. Hambatan yang paling mendasar adalah belum terbangunnya kebersamaan yang solid di antara individu yang plural dari segi etnik. Kebersamaan dan saling percaya secara massif hanya dapat dijalin jika difasilitasi oleh pemerintah daerah. Walaupun begitu, potensi pengembangan sistem pertahanan sosial ini masih ada. Karena secara personal rasa percaya dan kebersamaan ini masih terbentuk di lingkungan tetangga sebagai modal sosial yang mesti dikembangkan.

\section{Model kebijakan untuk pengembangan sistem pertahanan sosial berbasiskan modal sosial masyarakat lokal}

Dari sejumlah fakta di atas, ternyata masih banyaknya potensi ancaman terhadap kehidupan masyarakat di daerah perbatasan. Hal ini perlu diantisipasi dengan kebijakan yang relevan yang berdasarkan pada realita sosial masyarakat di Batam. Oleh karena itu, kebijakan yang dibuat mengacu pada realita sosial yang berkembang dalam masyarakat Batam yang majemuk. Ada beberapa elemen penting yang menjadi pertimbangan dalam membangun model kebijakan pertahanan sosial di Batam, sebagai daerah perbatasan.

Pertama, berhubungan dengan bentuk pertahanan sosial yang diinginkan. Seperti yang ditegaskan oleh Martin (1993:4) pertahanan sosial merupakan "...nonviolent community resistance to aggression as an alternative to military defence." Pertahanan sosial dibangun dari kesadaran komunitas untuk menolak kekerasan bersenjata sebagai bentuk alternatif untuk membangun sistem pertahanan. Syarat utama dalam membangun sistem pertahanan sosial ini adalah keharmonian dalam masyarakat. Keharmonian merupakan representasi dari bertemunya nilai-nilai individu dengan mengeliminasi perbedaan di antara mereka. Kota Batam dengan penduduk yang majemuk hidup dalam nilai-nilai yang plural. Akan tetapi, pluralitas nilai masyarakat di Batam ini juga menjadi ancaman terhadap keharmonian yang dibangun. Hal ini tentu berdampak pada usaha membangun pertahanan sosial dengan basis masyarakat.

Usaha membentuk sistem pertahanan sosial dalam masyarakat majemuk tentu lebih sulit dibandingkan dengan masyarakat yang homogen. Karenanya bentuk sistem pertahanan sosial juga berada pada tingkatan yang sederhana, yaitu ikatan sosial dalam bentuk forum warga. Forum ini dapat bersifat inter etnis maupun intra etnis yang frekuensi dan waktu kegiatannya justru tidak teratur dalam terorganisasi dengan baik. Dari aspek ini jelas, aktivitas forum warga ini masih bersifat tahapan awal dalam belum digunakan sebagai institusi yang aktivitasnya kompleks. Jika dikaitkan dengan sistem pertahanan sosial, maka forum warga lintas etnis ini juga belum memadai untuk menjadi inisiator membentuk sistem pertahanan sosial. 
Kedua, membangun model sistem pertahanan sosial juga memperhatikan mekanisme yang dapat mendorong keterlibatan aktif masyarakat, khususnya mereka yang ada di lapisan bawah. Dapat dilihat, masyarakat kelas bawah di Batam hampir tidak perah memikirkan adanya ancaman dari luar negara. Hal ini adalah implikasi dari rendahnya tingkat pendidikan mereka untuk memahami fenomena globalisasi sebagai ancaman. Realita ini jelas menyebabkan sulitnya pemerintah memobilisasi kelompok ini untuk terlibat dalam membangun sistem pertahanan sosial. Dorongan yang dilakukan oleh pemerintah daerah untuk penduduk Batam agar memperkuat jalinan komunikasi inter dan intra etnis dalam Forum Pembauran Kebangsaan belum terlihat efektif. Karenanya perlu ada kebijakan yang relevan dibuat pemerintah daerah agar asimilasi yang berlangsung dalam masyarakat dapat menjadi dasar pembentukan sistem pertahanan sosial.

Ketiga, tindakan yang menjadi bentuk respon individu ketika berhadapan dengan aktivitas yang mengancam kedaulatan mereka. Tidak semua masyarakat di daerah perbatasan yang dapat mengetahui dengan pasti seperti ancaman yang datang pada mereka. Hal ini tentu menjadi perhatian semua pihak, terutama pemerintah daerah untuk memberikan pemahaman terkait dengan bentuk ancaman tersebut. Pengetahuan masyarakat mengenai ancaman tersebut menjadi dasar tindakan yang mereka lakukan sesuai dengan prinsip pertahanan sosial. Seperti apa tindakan masyarakat tersebut? Menurut Martin (1993:7) ada tiga metode yang dapat dilakukan sebagai bagian respon dalam sistem pertahanan sosial, yaitu tindakan simbolik seperti pernyataan resmi diantaranya melalui pidato, surat, petisi, leaflet, dan banner. Metode lain dikenal dengan tindakan nonkooperatif seperti boikot, pemogokan, menolak membayar pajak dan lain sebagainya. Yang ketiga adalah melakukan intervensi dan memilih institusi alternatif untuk menyeimbangkan ancaman yang datang tersebut. Misalnya, membangun wacana melalui media, merusak dokumen data lain yang tersimpan dan sebagainya.

Pilihan tindakan ini cukup rasional dilakukan sepanjang masyarakat mengetahui apa yang terjadi di lingkungan mereka. Namun, tidak semua masyarakat dapat memahami apa yang sedang berlangsung di sekitar mereka. Seringkali tindakan yang diberikan seringkali terlambat dan tidak sesuai dengan ancaman yang datang. Karenanya dibutuhkan upaya nyata dari pemerintah daerah untuk mendorong masyarakat untuk memahami dengan baik potensi ancaman yang dapat menggugat kedaulatan negara dan kedaulatan individu.

Keempat, dasar nilai yang membangun sistem pertahanan sosial. Masyarakat yang majemuk hidup dengan nilai sosio-budaya yang beragam. Jika keberagaman sistem sosio-budaya ini tidak dapat diasimilasikan, maka kebersamaan dan keharmonian, sebagai dasar sistem pertahanan sosial di daerah perbatasan sulit direalisasikan. Kehidupan masyarakat di Kota Batam sangat dipengaruhi oleh sistem sosial yang beragam ini. Walaupun, sistem sosio-budaya masyarakat Melayu Riau berkembang dalam keseharian kehidupan masyarakat Batam, namun tidak berarti nilai sosiobudaya etnis lain tidak berperan. Kehidupan masyarakat Batam yang mengelompok berdasarkan etnis, terutama di daerah-daerah kantong industri menyebabkan munculnya dominasi nilai sosiobudaya di daerah tersebut (Isrofil 2013).

Pertimbangan terhadap keempat elemen di atas dapat digambarkan ke dalam tahapan pembentukan model yang dapat diakomodasi oleh pembuat kebijakan ke dalam tiga tahapan, yaitu tahapan penyamaan persepsi terkait dengan cara mewujudkan kebersamaan dan harmonisasi di lingkungan masyarakat, khususnya di tingkat Rukun Tetangga/Rukun Warga. Hal ini dapat dilakukan dengan cara melibatkan pemerintah di tingkat terendah, yaitu kelurahan yang ada di Pulau Batam. Peran dan fungsi pemerintah di kelurahan adalah memperkuat sistem nilai sosial budaya masyarakat dengan cara mengasimiliasikan nilai-nilai mereka ke dalam nilai bersama yang menjadi identitas baru, namun tidak menghilangkan sistem sosio-budaya mereka yang lama. Melalui asimilasi ini terjadi kontak di antara individu-individu yang membawa sistem nilai masing-masing. Kontak di antara kelompok etnik ini juga menghasilkan persaingan dalam arti positif sehingga pada tahapan tertentu terjadi saling mengakomodasi nilai-nilai kultur yang ada. Saling mengakomodasi nilai yang ada ini mendorong munculnya kerjasama di antara kelompok etnik yang hidup di daerah Batam. 
Akan tetapi, kuatnya penetrasi nilai globalisasi yang mengalir masuk di daerah perbatasan ini, ikut mempengaruhi sikap masyarakat dalam memahami lingkungan sosialnya. Jika sistem nilai di lingkungan mereka ini tidak solid tentu membawa dampak pada kepribadian mereka. Di sinilah dibutuhkan kerjasama di antara etnik yang beragam dengan basis RT/RW yang ada di kelurahan. Sebenarnya, Pemerintah Daerah Kota Batam sudah melaksanakan proses asimilasi ini melalui pembentukan Forum Pembauran Kebangsaan dan Forum Kewaspadaan Dini Masyarakat. Forum ini adalah salah satu wujud penyamaan persepsi masyarakat di Batam untuk mewujudkan harmonisasi kehidupan karena majemuknya sistem nilai mereka. Namun, pada aspek tertentu keberadaan forum ini terasa belum maksimal karena cenderung bersifat formal dan pembentukannya diinisiasi oleh pemerintah daerah. Idealnya, pembentukan forum kerjasama lintas etnik seperti ini muncul dari inisiasi masyarakat dan difasilitasi oleh pemerintah daerah.

Tahapan kedua adalah identifikasi bersama dalam menemukan tindakan yang sesuai untuk merespon pengaruh yang datang kepada mereka. Identifikasi bentuk tindakan ini dapat dilakukan karena adanya kesamaan persepsi di antara masyarakat walaupun berbeda nilai sosio-budayanya. Melalui kebijakan asimilasi, terdapat kerjasama yang erat di antara kelompok etnik untuk mewujudkan kepentingan mereka. Apalagi ditambah dengan faktor kebangsaan, agama, suku bangsa yang dapat dipahami bersama menjadi pertimbangan dalam membangun kerjasama ini. Keberhasilan menemukan bentuk tindakan bersama untuk merespon pengaruh nilai-nilai luar komunitas ini dapat menghasilkan solidaritas sosial individu yang menjadi modal dasar dalam membentuk sistem pertahanan sosial. Biasanya, solidaritas yang terbentuk dari kelompok ini cenderung bersifat organik karena heterogennya etnik yang tinggal di Batam dengan pelbagai macam latar belakang sosial dan ekonomi dan tinginya sifat saling ketergantung mereka satu dengan yang lain.

Tahapan ketiga adalah proliferasi jaringan dengan perluasan wilayah kerjasama dalam rangka memperkuat sistem pertahanan sosial. Proliferasi jaringan di antara etnik yang ada adalah untuk memperluas wilayah sistem pertahanan sosial yang tidak hanya terbatas pada geografis kelurahan, tapi juga meliputi kecamatan dan kota secara keseluruhan. Melalui cara ini, sistem pertahanan sosial ini akan mudah diintegrasikan ke dalam gerakan kolektif dalam menangkal segala bentuk ancaman yang datang kepada masyarakat. Pemerintah Kota Batam dapat memfasilitasi proliferasi jaringan ini dalam berbagai bentuk aktivitas yang bersifat masif secara periodik. Jika hal ini dapat dilakukan, maka penguatan sistem pertahanan sosial berbasiskan sistem sosial budaya masyarakat dapat dibentuk.

Proliferasi jaringan sebenarnya juga terkait dengan Sistem Pertahanan Rakyat Semesta (Sishankamrata) yang sudah ada sebelumnya. Perbedaan yang mendasar dari Sishankamrata ini dengan proliferasi jaringan dalam sistem pertahanan sosial ini adalah pada sistem nilai sosiobudaya yang menjadi basisnya. Jika pada mekanisme Sishankamrata yang ada pada buku putih Departemen Pertahanan ditujukan untuk menggalang kekuatan masyarakat dengan cara mobilisasi dalam menghadapi ancaman militer terhadap wilayah Negara, pada proliferasi jaringan ditujukan untuk memperkuat solidaritas organik masyarakat di daerah perbatasan dengan cara membangun kesadaran otonom mereka untuk mengantisipasi pengaruh buruk globalisasi. 


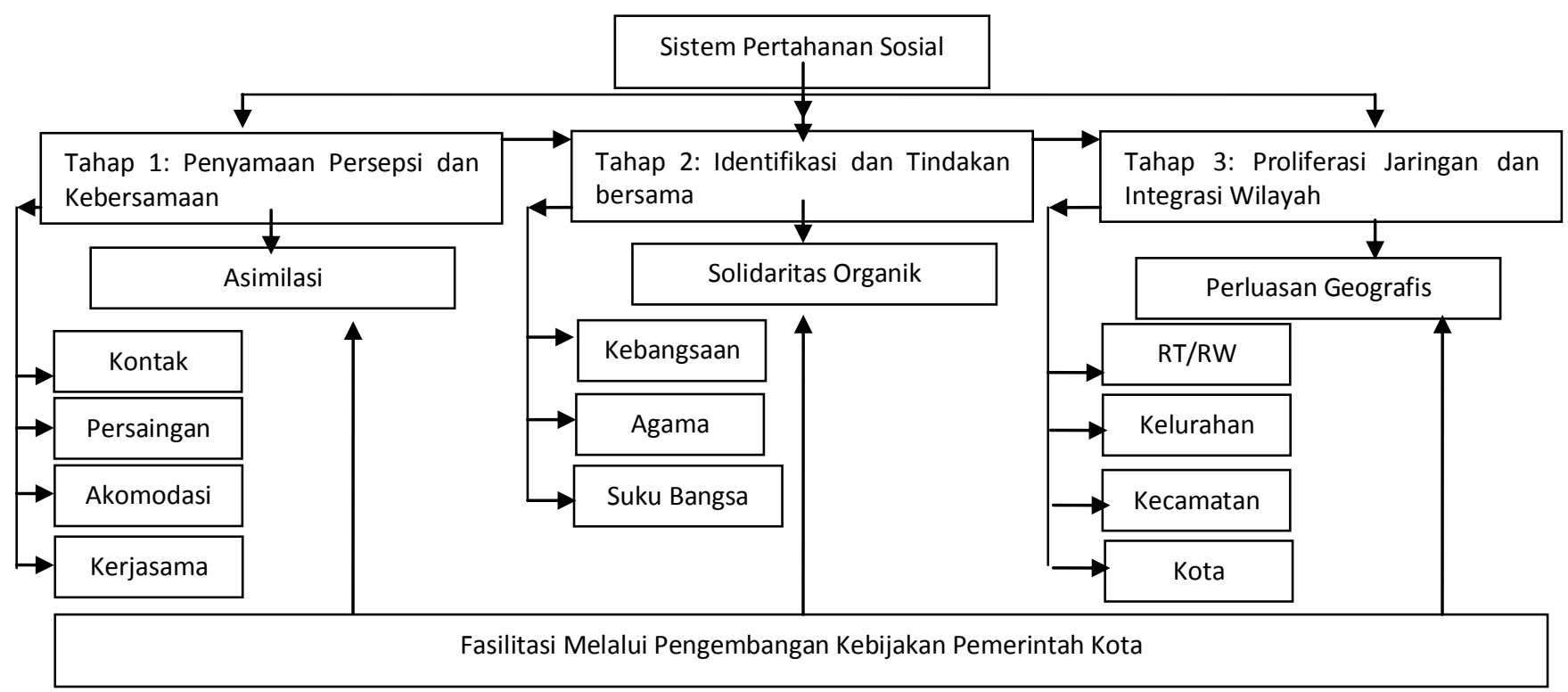

Gambar 2.

Model pengembangan sistem pertahanan sosial masyarakat di perbatasan

Ketiga tahapan pengembangan sistem pertahanan sosial ini sebenarnya terkait dengan modal sosial yang dimiliki masyarakat di daerah perbatasan. Oleh karenanya, pemerintah daerah harus dapat mengembangkan dan memperkuat sistem sosio-budaya masyarakat yang ada di daerah perbatasan. Konteksnya tentu dengan memfasilitasi pengembangan sistem sosio-budaya masyarakat di Kota Batam yang sangat plural. Dengan cara ini, disadari atau tidak pemerintah daerah telah membantu mengembangkan modal sosial masyarakat yang keadaannya mulai kritis karena kuatnya pengaruh nilai budaya asing yang dibawa masuk melalui globalisasi.

\section{Simpulan}

Artikel ini telah merumuskan model pengembangan sistem pertahanan sosial yang terdapat dalam kehidupan masyarakat di daerah perbatasan. Hal yang paling penting dalam mengembangkan sistem pertahanan sosial ini adalah dengan menggali potensi modal sosial yang dimiliki, terutama untuk mengantisipasi ancaman yang datang kepada masyarakat dan negara. Pada bagian simpulan ini perlu ditegaskan bahwa model kebijakan pengembangan sistem pertahanan sosial masyarakat dapat dilakukan dengan cara memperbaharui kebijakan yang sudah ada, misalnya yang terkait dengan asimilasi dalam masyarakat Kota Batam yang plural. Ini dapat dilakukan dengan memperbanyak kontak di antara mereka, membangun persaingan yang positif, dapat mengakomodasi dan menjali kerjasama di antara etnik yang ada. Jika asimilasi ini dapat dilakukan, maka pemerintah kota juga perlu memperkuat solidaritas organik yang terjalin dalam keseharian mereka. Ini bertujuan agar identifikasi dan tindakan bersama terkait dengan ancaman yang datang dapat diminimalkan. Solidaritas organik ini bisanya dapat dikembangkan dengan mengedepankan semangat kebangsaan, agama dan suku bangsa. Terakhir terkait dengan kebijakan proliferasi jaringan dan integrasi wilayah, maka kebijakan yang dapat dikembangkan pemerintah kota adalah memperluas wilayah geografis. Ini bertujuan agar semua eleman masyarakat di Kota Batam terlibat dalam membangun sistem pertahanan sosial. 


\section{Daftar Pustaka}

Asrinaldi \& Yoserizal (2013) Ancaman terhadap pengembangan sistem pertahanan sosial daerah perbatasan kota Batam. Mimbar 29(1).

Bantun D (2013) Wawancara dengan penulis 2 Juli 2013. Batam [Rekaman milik penulis].

Chenhall RH, Hall M \& Smith D (2010) Social capital and management control systems: a study of a non-government organization. Accounting, Organization and Society, 35:737-756.

Claessen HJM \& Oosten JG (1996) Introduction. In: Henri JMC \& Jarigh GO (eds) Ideology and the formation of early states. Leiden: Brill. 1-23.

Crouch H (1978) The army and politics in Indonesia. New York: Cornell University Press.

Departemen Pertahanan (2008) Buku putih sistem pertahanan Indonesia 2008. Jakarta: Penerbit Dephan.

Fukuyama F (1995) The social virtues and the creation of prosperity. New York: Free Press.

Ganewati W (2009) Tetangga baru, masalah baru: Timor Leste, keamanan di perbatasan dan pengelolaannya. Dalam: Ganewati W (Ed) Keamanan di Perbatasan Indonesia-Timor Leste: Sumber Ancaman dan Kebijakan Pengelolaannya. Jakarta: Pustaka Pelajar-P2P LIPI.

Gregg RB (1966) The power of nonviolence. New York: Schocken.

Greenstein FI (1975) Personality and politics: Problems of evidence, influence, and conceptualization. New Jersey: Princeton University Press.

Hurd I (2007) After anarchy: legitimating and power in the United Nation security. New Jersey: Princeton University Press.

Isrofil (2013) Wawancara dengan penulis 2 Juli 2013. Batam [Rekaman milik penulis].

Istanto FS (1992) Perlindungan penduduk sipil dalam pertahanan rakyat semesta. Yogyakarta: Penerbit Andi Offset.

Kaplan MA (2005) System and process in international politics. Colchester UK: ECPR Press.

Lowndess V \& Pratchett L (2008) Public policy and social capital. In: Dario C, Jan WVD \& Guglielmo W (ed) The handbook of Social Capital. Oxford: Oxford University Press. 677707.

Martin B (1987) Social defence: elite reform or grassroots initiative? Social alternatives. Gene Sharp's theory of power. Journal of Peace Research 6 (2): 213-222.

Martin B (1993) Social defense, social change. London: Freedom Press.

Nasution AH (1980) Dwi fungsi ABRI: pada mulanya dan kini. Prisma 12:39-43.

Putnam R (1993) Making democracy work: Civic traditions in modern Italy. Princeton NJ: Princeton University Press.

Sofiyan E (2013) Wawancara dengan penulis 2 Juli 2013. Batam [Rekaman milik penulis].

Sugiyanto (2013) Wawancara dengan penulis 2 Juli 2013. Batam [Rekaman milik penulis].

Suryohadiprojo S (2005) Si vis pacem para bellum: Membangun pertahanan negara yang modern dan ffektif. Jakarta: Gramedia.

Tempo (2013) Tempo Interaktif. 3 November 2013. Jakarta: situs [diakses pada tanggal 3 November 2013] http://www.tempo.co/read/news/2013/10/24/058524194/Konflik-LahanTanjung-Uma-Batam-Rusuh.

Wollongong SA (1994) Social defence and community development. Australian Social Work 47(1):48-54.

Yulidasril (2013) Wawancara dengan penulis 2 Juli 2013. Batam [Rekaman milik penulis].

Zuckerman AS (2005) Returning to the social logic. In: Alan SZ (ed) The Social Logic of Politics: Personal Network of Politics as Contexts for Political Behavior. Philadhelpia PA: Temple University Press. 3-2 